\title{
窒化物半導体による青色レーザーおよび光電変換素子の現状と展望
}

\author{
竹内 哲也 ${ }^{1}$, 岩谷 素顕 ${ }^{1}$, 上山 智 ${ }^{1}$, 赤崎 ${ }^{\text {勇 }}{ }^{1,2}$ \\ 1名城大学 理工学部 ( $7468-8502$ 名古屋市天白区塩釜口1-501) \\ 2名古屋大学 赤㠃記念研究センター ( ₹464-8601 名古屋市千種区不老町)
}

\section{Status and Prospects of GaN-Based Blue Lasers and Photo Detectors}

\author{
Tetsuya TAKEUCHI, ${ }^{1}$ Motoaki IWAYA, ${ }^{1}$ Satoshi KAMIYAMA, ${ }^{1}$ and Isamu AKASAKI ${ }^{1,2}$ \\ ${ }^{1}$ Faculty of Science and Technology, Meijo University,1-501 Shiogamaguchi, Tempaku-ku, Nagoya 468-8502 \\ ${ }^{2}$ Akasaki Research Center, Nagoya University, Furo-cho, Chikusa-ku, Nagoya 464-8601
}

(Received August 10, 2018)

\begin{abstract}
This paper describes the status and prospects of GaN-based blue laser diodes and solar cells in terms of using optical wireless power transmission systems. Reported values of the power conversion efficiency, which is one of the most important characteristics of the emitters and the detectors in the systems, were summarized. These are the reported values: about $40 \%$ for blue edge-emitting laser diodes, less than $10 \%$ for blue vertical-cavity surface-emitting lasers, and about $30 \%$ for solar cells at $390-400 \mathrm{~nm}$ wavelength. Since optical wireless power transmission with blue lasers is beginning to attract attention, device developments towards such an application will be pursued.
\end{abstract}

Key Words: GaN, Laser diode, Solar cell, Efficiency, Wireless power transmission

1. はじめに

近年, 光を用いた無線給電が注目されており ${ }^{1)}$, 窒化 物半導体による青色レーザーと受光素子を用いた無線給 電に関する報告もなされた ${ }^{2}$. 本稿では, 給電技術とし て重要な要素であるエネルギー変換効率に着目し, 端面 発光型と近年進展の著しい面発光型の青色レーザー,さ らに, 窒化物半導体受光素子のひとつである太陽電池に 関して，その現状と展望について紹介する。

\section{2. 窒化物半導体による青色レーザー}

\section{1 端面発光型}

電流注入による窒化物半導体からの誘導放出が1995年 に実現され ${ }^{3)}$ ，翌年，レーザー発振が実現した4)。それ 以来, 20 年以上が経過し, 波長域拡大, 高出力化, 高効 率化が着実に進んでいる。現在では，波長約 $460 \mathrm{~nm}$ おいて, 光出力 $5 \mathrm{~W}$ 以上, エネルギー変換効率 (Power Conversion Efficiency: PCE) 約 $40 \%$ という值が複数の研究機 関から報告されている ${ }^{5-7)}$. しきい值電流密度も $1 \mathrm{kA} / \mathrm{cm}^{2}$ 以下と良好な值が実現されている。記を実現する詳細 な素子層構造は明らかにされていないが, ITO電極利用 による素子抵抗や内部損失の低減 $\left(1 \mathrm{~cm}^{-1}\right.$ 未満 $)$ が報告さ れている7).

$$
\text { 一般的に高効率半導体レーザーを実現するためには， }
$$

(1)高い注入効率，(2)高い光閉じ込め係数，(3)低い内部損 失の三つが重要である。ここで, 先行しているGaAs系 高効率赤外レーザーの設計思想を眺めてみると, (1)と (3) を優先するアプローチが採用され，970 nmで動作する InGaAs端面レーザーで73\%のPCEが実現されている ${ }^{8)}$. 比較的低いドーピングにて，高い注入効率 $(96 \%)$ ，低い 内部損失 $\left(\sim 1.5 \mathrm{~cm}^{-1}\right)$, さらには低い素子抵抗(微分抵 抗3.3 $\mathrm{m} \Omega$ )を実現したと記載されている。この赤外レー ザーでのPCEの值に比べ，上述した窒化物半導体青色 レーザーのPCEが低い值で留まっている要因は，高い注 入効率と低い内部損失の両立, それに加えて低い素子抵 抗の実現が困難であるためと考えられる。ワイドギャッ プ材料では, キャリア濃度が低く，移動度も低い，それ ゆえ，窒化物半導体において，低い内部損失を求めて低 いドーピング濃度を用いると，キャリア注入や素子抵抗 の面で大きなデメリットになると思われる。赤色レー ザーのPCEも赤外に比べ低い值に留まっている $(45 \%)^{9)}$ ことも上述した点が理由のひとつになっていると推測さ れる。ささに, 駆動電圧の面では, c面窒化物半導特有 の自発・ピエゾ分極による内蔵電位増加も解決すべき課 題と考えられる。すなわち, 今後もPCEのゆるやかな改 善は期待されるものの，赤外レーザーと同等の值まで到 達し得るかどうかが懸念される。

これに対して我々は，(1)と(2)を優先するアプローチに 青色レーザー高効率化の可能性があるのではないかと考 
えている. 特に, (2)の高い光閉じ込め係数実現のため

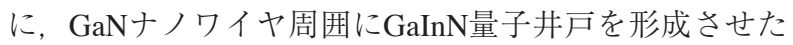
量子殼活性層 ${ }^{10,11)}$ や, 低屈折率AlInNクラッド層 ${ }^{12)}$ など の要素構造の検討を進めている。通常の半導体レーザー では，光閉じ込め係数は数\%であるが，3次元的な構造 である量子殼構造では，6.5-9.0\%になる可能性が理論検 討により見積もられている。また，AlInNクラッド層で は, GaNに格子整合しつつ, 大きな比屈折率差が得ら れ, 赤外材料で良く知られた, GaAs活性層に対するAl$\mathrm{GaAs}$ クッド層, あるいはInGaAsP活性層に対するInP クラッド層に匹敵する比屈折率差が実現する。特に, 窒 化物半導体において長波長領域である緑色領域にて, 従 来の $\mathrm{AlGaN}$ クッド層に対して約5倍の比屈折率差を実 現できることが報告されている吕．このAlInNは，後述 するように結晶成長が困難であったが, $\mathrm{GaN}$ との多層膜 構造を用いる ${ }^{14)}$, あるいは結晶成長条件の最適化 ${ }^{12)}$ 進 めることで, 高性能素子に要求される高品質 $\mathrm{A} I \mathrm{InN}$ 結晶 が作製され始めている。 今後は, こうした新しい要素構 造を青色レーザーに適用し, その効果を検証するととも に，赤外レーザー並みのPCEを実現するための方策を明 確にしていく必要がある。

\section{2 面発光型}

電流注入による窒化物半導体面発光レーザーの実現 は，2008年であり，端面発光型の実現から12年を要し た ${ }^{15,16)}$. この最大の理由は縦型共振器の形成, すなわち 窒化物半導体による高品質多層膜反射鏡 (Distributed Bragg Reflector: DBR)の形成が困難だったからであろ う. Higuchiらは, 上下共に誘電体DBRを利用すること で室温連続動作 ${ }^{15)}$ を，Luらは，AlN/GaN DBRを下部

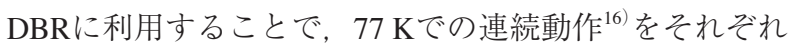
初めて実現した。上下共に誘電体DBRを用いると，高 反射率を有するDBR自体は容易に形成できる一方, 縦 型共振器を形成するために, 基板を剥離する煩雑な工程 が必要になる。一方, 半導体によるDBRでは, それ自 体の結晶成長が困難である一方, 一旦良好なDBRが形 成できれば，引き続き活性層を含む共振器まで容易に形 成可能である。 それぞれメリットとデメリットが対比す る関係になっている。

このような状況下で, Cosendeyらは, AlInNとGaNを 用いて多層膜反射鏡を形成し，室温パルス発振を実現さ せた ${ }^{17)}$ 。この構造では, AlInNとGaNが格子整合するた め, 赤外面発光レーザーに用いられる格子整合AlAs/ GaAs DBR 同等の高い結晶性の可能性を有する. 一方 で, AlInNの結晶成長では, In取り込みのため, GaInN
と同様の $800^{\circ} \mathrm{C}$ 程度まで成長温度を下げなければならず, 高品質結晶を得ることが困難であった，従来，低温成長 によるマイグレーション低下を補うため, GaInNと同 様， $0.2 \mu \mathrm{m} / \mathrm{h}$ 以下の低い成長速度を使用する必要があっ た。一方で, この低い成長速度は，数 $\mu \mathrm{m}$ 厚を必要とす るDBR形成には極めて不利であった。そこで, 我々は, AlInNに対する成長パラメータを系統的に検討した結 果, 成長温度を $50^{\circ} \mathrm{C}$ 程度上昇させることで, 成長速度 が $0.5 \mu \mathrm{m} / \mathrm{h}$ 以上であっても良好な表面，かつ結晶性を有 するAlInNが成長できることを見出した ${ }^{18)}$ 。この成長条 件を利用して40ペアのAlInN/GaN DBRを形成したとこ ろ，設計波長 $410 \mathrm{~nm}$ で $99.9 \% ， 520 \mathrm{~nm}$ で $99.4 \%$ の射率 が実現した。ささらに，報告されている屈折率值を用いた 理論計算と極めて良く一致することもわかった。 そし て, このAlInN/GaN DBRを用いたGaInN面発光レーザー を作製した結果，最大光出力として計 $5.2 \mathrm{~mW}$ (上部誘電 体DBRから $1.0 \mathrm{~mW}$ ，下部AlInN/GaN DBRから $4.2 \mathrm{~mW}$ ) を実現した ${ }^{19)}$ 。しきい值電流密度は, $10.3 \mathrm{kA} / \mathrm{cm}^{2}$ であ り, 微分抵抗は $140 \Omega$ であた。一方で, 外部微分量子 効率は $13 \%$, PCEは5\%であり，依然として改善の余地は 大きい

このPCEを改善するためには，しきい值電流密度の低 減, 外部微分量子効率の増大, そして素子抵抗の低減が 必要である。最初の二つの改善に向けて，現状の窒化物 半導体面発光レーザーでは, 内部損失の低減が鍵を握っ ていると考えられる。窒化物半導体面発光レーザーで は，赤外面発光レーザーで用いられている酸化AlGaAs (低屈折率材料)による電流狭窄構造がなく, それによっ てもたらされる光導波構造も存在しない. Hashemiら は, 窒化物半導体面発光レーザーで主流となっている $\mathrm{SiO}_{2}$ 開口と ITO電極の組み合わせによる電流狭窄構造で は，意図せず反導波構造が形成され，横方向への光の散 逸による損失が $40 \mathrm{~cm}^{-1}$ 程度存在することを理論計算に より予測した。また，段差構造や埋め込み構造により， 疑似的な屈折率段差による導波構造が実現できることも 提案した ${ }^{20)}$. これまでに, 光導波構造を形成する試みが いくつか行われており，それをTable 1 にまとめる。 大 きく分けて, 誘電体などにより屈折率段差を形成する手 法 $^{21-23)}$ と, イオン打ち込みにより屈折率段差を形成する 手法 ${ }^{24)}$ が試みられている。これらの手法において, Kuramotoらの埋め込み構造を用いる手法において, 最大光 出力が $6 \mathrm{~mW}, \mathrm{PCE} 75 \%$ という良好な素子特性が報告さ れている ${ }^{23)}$. 現時点では, 結晶に直接的なダメージが入 らず，かつ物理的段差のない，すなわち光に対する散乱 要因の少ない構造が良好な結果をもたらしているように

Table 1 Optical confinement structures in GaN-based VCSELs.

\begin{tabular}{|c|c|c|c|c|}
\hline Affiliation & Stanley/Meijo ${ }^{23)}$ & Meijo Univ. ${ }^{22)}$ & $\mathrm{UCSB}^{21)}$ & $\mathrm{UCSB}^{24)}$ \\
\hline Year & 2018 & 2018 & 2016 & 2015 \\
\hline Structure & $20 \mathrm{~nm}$ buried $\mathrm{SiO}_{2}$ & $15 \mathrm{~nm} \mathrm{Nb}_{2} \mathrm{O}_{5}$ step & 30nm air-gap & $\mathrm{Al}$ implantation \\
\hline Refractive index difference $(\%)$ & 0.26 & 1.5 & 2.1 & 1.8 \\
\hline Light output power (mW) & 6 & 0.88 & 0.18 (pulsed) & 0.012 (pulsed) \\
\hline
\end{tabular}


思われる。

最終的に内部損失に関しては, ITO電極による吸収や 電流注入のための不純物ドーピングに伴う吸収が課題と して残ってくるだろう。我々の簡単な計算によると，そ れぞれ $10 \mathrm{~cm}^{-1}$ 未満の值が見積もられる. 赤外面発光 レーザーでその有用性が実証されている，埋め込みトン ネル接合による電流狭窄構造や, 光強度分布を考慮した 不純物変調ドーピングによりさらなる損失低減が可能と 考えられる。

続いて，素子抵抗の低減に関して述べる，窒化物半導 体は抵抗率が高いため，素子抵抗は高くなりやすい。さ らに, 半導体DBRであっても不純物を添加しない場合 は絶縁性であるため, いわゆるイントラキャビティコン タクトとなり, Fig. 1 (a)の赤線が示す横方向への電流経 路によって素子抵抗が高くなる. ゆえに, 赤外面発光 レーザーで広く用いられている, Fig. 1(b)に示す導電性 DBRによる縦方向電流注入の実現が強く望まれる.

我々は, 窒化物特有の界面に生じる自発分極の影響を考 慮したSi変調ドーピングを上述したAlInN/GaN DBRに施 し $^{14,25)}$ ，さらにごく最近，AlAs/GaAs DBRでも用いられ ている組成傾斜層を界面に設けることで, 再現性良く導 電性AlInN/GaN DBRが実現できることを明らかにし た。これを下部DBRとして用いることで，Fig. 2 に示す ように, これまでアンドープDBRの場合には, 上述し

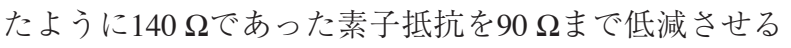
ことができた ${ }^{26)}$. 光出力も, 現時点で上述した最大出力 には及ばないものの, $1 \mathrm{~mW}$ 以の光出力が実現してお り, さらなる最適化により高出力と低抵抗の両立が可能 と考えられる。

\section{3. 窒化物合半導体による太陽電池}

窒化物半導体を用いた受光素子としては, 太陽電池が 研究対象の中心になっている. 従来の化合物半導体では

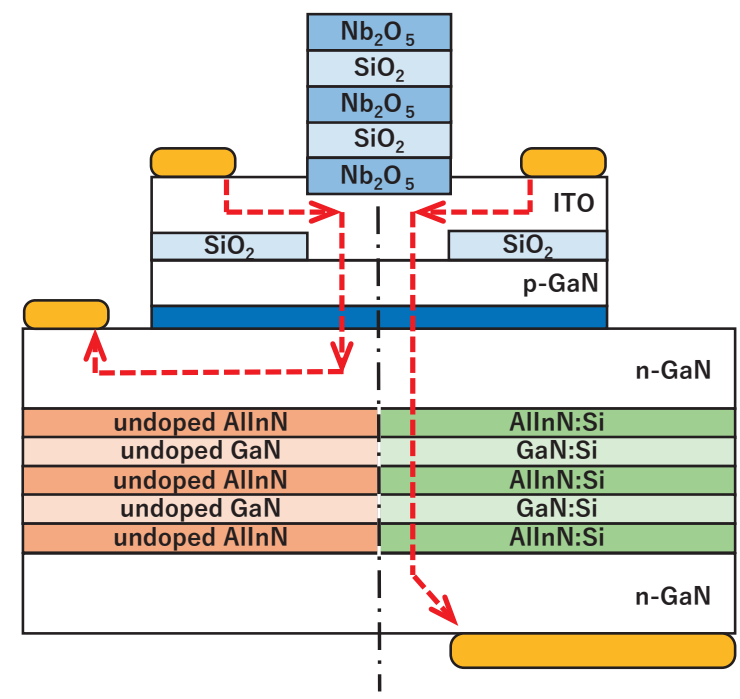

(a) undoped DBR

(b) Si-doped DBR

Fig. 1 Current paths in GaN-based VCSELs with (a) insulating DBR and (b) conducting DBR.

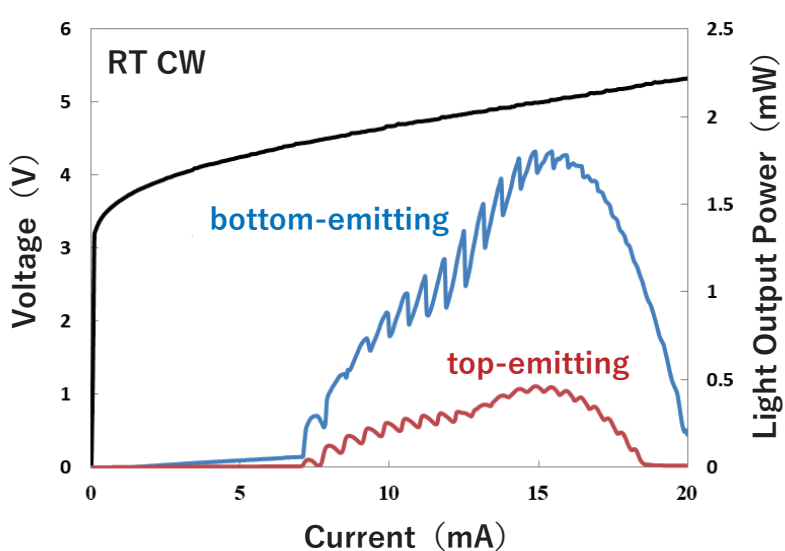

Fig. 2 I-L-V characteristics of a GaN-based VCSEL with a conducting DBR.

対応できない短波長領域を担う材料として, さらに近赤

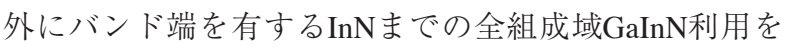
踏まえた新しい太陽電池としての可能性が検討されてい る.この窒化物半導体太陽電池の動向と課題は, 文 献27）に詳しくまとめられている。ここでは, その窒化 物半導体太陽電池の現状と, 光無線給電用受光素子とし ての課題について述べる.

代表的な窒化物半導体太陽電池の構造(吸収層) と特性 をTable 2 にまとめる ${ }^{28-32)}$. 太陽電池のエネルギー変換効 率として約3\%が報告されている. 外部量子効率として は, $390 \mathrm{~nm}$ 付近にて約60\%を超える高い值が報告されて いる。 これらの構造では, $60 \mathrm{~nm} \mathrm{GaInN}$ 単層や, 数10周 期の $3 \mathrm{~nm} \mathrm{GaInN}$ 井戸層が利用されており，電極での反射 率などを考慮すると $90 \%$ 超える内部量子効率が実現し ていると考えられる、ゆえに, 無線給電用受光素子とし ては，波長390-400 nmを設計波長とすることで，この 高い内部量子効率が利用可能である. 最終的に外部量子 効率をさらに向上させるために，GaInN吸収層をさらに 厚くする，あるいは面発光レーザーと同様にDBRによ る共振器構造を用いて吸収領域の実効光路長を長くする ことなどが考えられる。

一方で，課題は開放電圧の低下である。 Table 2 に 記載されているように, 吸収のピーク波長は3 $390 \mathrm{~nm}$ $(3.2 \mathrm{eV})$ 付近, 吸収端波長は $440 \mathrm{~nm}(2.8 \mathrm{eV})$ 付近であ る。このような状況にもかかわらず，得られる開放電圧 は2 V程度まで低下しており, 電圧におけるエネルギー 損失が大きい。この要因を明確にし，対策を講じる必要 がある。

さらに, 光無線給電用受光素子として検討すべき特性 として, 照射光密度依存性が挙げられる。通常, 太陽電 池における照射光密度は $100 \mathrm{~mW} / \mathrm{cm}^{2}(1 \mathrm{SUN})$ である. 一方, 光無線給電用受光素子では, より高い照射光密度 が予想される。ここでは, 光無線給電における照射光密

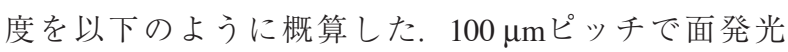
レーザーを $1 \mathrm{~cm}$ 四方に並べると，その中に 10000 個の面 発光レーザーが存在する。各面発光レーザーが $10 \mathrm{~mW}$ の光を出射すると, 全光出力は $100 \mathrm{~W}$ あ゙あ. 仮 に，同じサイズの太陽電池でその光を全て受光すると 
Table 2 Structures and characteristics of GaN-based solar cells.

\begin{tabular}{|c|c|c|c|c|c|}
\hline Affiliation & Arizona State Univ. ${ }^{32)}$ & $\mathrm{CNRS}^{31)}$ & Meijo Univ. ${ }^{30)}$ & $\mathrm{UCSB}^{29)}$ & Texas Tech Univ. ${ }^{28)}$ \\
\hline Year & 2018 & 2016 & 2011 & 2011 & 2010 \\
\hline absorption layer & 30-pair 3nm GaInN & $60 \mathrm{~nm}$ GaInN & 50-pair 3nm GaInN & $60 \mathrm{~nm}$ GaInN & 12-pair 3nm GaInN \\
\hline PCE $(\%)$ & 1.85 & 0.49 & $2.5(1.5$ suns $)$ & 1.57 & 2.95 \\
\hline $\begin{array}{l}\text { External quantum } \\
\text { efficiency }(\%)\end{array}$ & 65 & 79 & 59 (1.5 suns) & 72 & - \\
\hline $\begin{array}{l}\text { Peak absorption } \\
\text { wavelength }(\mathrm{nm})\end{array}$ & 390 & 387 & 390 & 380 & - \\
\hline $\begin{array}{l}\text { Absorption edge } \\
\text { wavelength (nm) }\end{array}$ & 450 & 440 & 440 & 430 & - \\
\hline $\begin{array}{l}\text { Open-circuit } \\
\text { voltage }(\mathrm{V})\end{array}$ & 2.2 & 0.48 & 1.78 (1.5 suns) & 1.89 & 1.8 \\
\hline $\begin{array}{l}\text { Short-circuit current } \\
\left(\mathrm{mA} / \mathrm{cm}^{2}\right)\end{array}$ & 1.39 & 2.56 & 3.08 (1.5 suns) & 1.06 & 2.56 \\
\hline Fill factor $(\%)$ & 60.52 & 40 & 70 (1.5 suns) & 78.6 & 64 \\
\hline
\end{tabular}

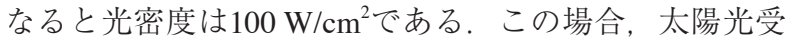
光の場合に比べ，3桁も高い值になる。この照射光強度 依存性として, 我々はITO電極を利用した太陽電池にお いて, 光強度を $20 \mathrm{~W} / \mathrm{cm}^{2}(200 \mathrm{sun})$ 以上まで増大させる ことで, 解放電圧が $2.2 \mathrm{~V}$ まで向上し, 太陽電池として のエネルギー変換効率が $4.0 \%$ まて改善されることを報 告した ${ }^{33)}$ 。これらの改善は, 光強度増大によるキャリア 密度増大に起因しており，他材料系でも同様の報告が ある。一方で, 照射強度密度が増大 $\left(\sim 10 \mathrm{~W} / \mathrm{cm}^{2}\right)$ する と, 変換効率が大きく低下する例も報告されている ${ }^{2}$. これは, 高い照射強度に伴う素子温度上昇による特性 の低下と報告されている。ここまで示した結果は, 広 いスペクトルを有する疑似太陽光を用いた場合の結果 である.今後は, 単色光による窒化物半導体受光素子 の特性検討とその理解が望まれる。

最後に，上述した青色レーザーと窒化物半導体太陽電 池の特性に関する報告值を用いて，光無線給電システム におけるエネルギー効率を概算する。青色半導体レー ザーではPCEが約40\%であった，出射された光が，全く ロスなく太陽電池に到達し, かつ太陽電池の受光効率に おいて, 照射光密度依存性がないと仮定する。この場 合, 外部量子効率が70\%, 開放電圧の低下分が $65 \%$ $(2.0 \mathrm{eV} / 3.1 \mathrm{eV})$, さらに, 最適動作点を与える曲線因子 がおよそ70\%であることから，波長390-400 nmにおける 受光側のPCEは約30\%と見積もられる. よって, システ 厶全体としてのエネルギー効率は，10\%程度である。給 電システムとしては低い值であり, 効率改善が必須であ る。一方で, 無線であること, そして青色光であること の特徵に着目し，海中での無線給電(および通信)に関す る議論が注目され始めている 。こうした動きに併せて, 光無線給電という観点における窒化物半導体素子の研究 開発も早々に必要になると思われる。
4. まとめ

本稿では, 光無線給電の観点から, 青色レーザーと窒 化物半導体太陽電池の現状と課題を記載した。 エネル ギー変換効率の現状は，端面青色レーザーで約 $40 \%$ ，面 発光型で10\%未満である。そして太陽電池の波 長390-400 nmの単色光におけるエネルギー変換効率は 約 $30 \%$ と見積もられる。赤外領域で動作する半導体素子 に比べ，低い值である一方，青色レーザーが必要な光無 線給電に関する議論も開始された。今後，光無線給電へ の利用を見据えた検討を進めることで，素子特性の改善 が進み，青色領域で動作する素子の可能性がさらに高ま ることを期待する.

謝 辞

本研究課題の一部は文科省・私立大学研究ブランディ ング事業（2016-2020），文科省「省エネルギー社会の実 現に資する次世代半導体研究開発」, 日本学術振興会 · 科研費基盤研究A（15H02019，17H01055），新学術領域 研究 (16H06416), JST CREST (16815710)の援助によっ て行われました。

\section{参考文献}

1) 宮本 智之: O plus E 40 (2018).

2) C. D. Santi, M. Meneghini, A. Caria, E. Dogmus, M. Zegaoui, F. Medjdoub, B. Kalinic, T. Cesca, G. Meneghesso, and E. Zanoni: Materials 11 (2018) 153.

3) I. Akasaki, H. Amano, S. Sata, H. Sakai, T. Tanaka, and M Koike: Jpn. J. Appl. Phys. 34 (1995) L1517.

4) S. Nakamura, M. Senoh, S. Nagahama, N. Iwasa, T. Yamada, T. Matsushita, H. Kiyoku, and Y. Sugimoto: Jpn. J. Appl. Phys. 35 (1996) L74

5) S. Masui, Y. Nakatsu, D. Kasahara, and S. Nagahama: Proc. SPIE 10104 (2017) $101041 \mathrm{H}$.

6) H. König: Int. Conf. Nitride Semicon. (2017) 12, B.7.2.

7) M. Murayama, Y. Nakayama, K. Yamazaki, Y. Hoshina, H.

\footnotetext{
${ }^{\dagger}$ ALANコンソーシアム, https://www.jeita.or.jp/japanese/topics/2018/0521.pdf
} 
Watanabe, N. Fuutagawa, H. Kawanishi, T. Uemura, and H. Narui: Phys. Stat. Sol. A 215 (2018) 1700513.

8) M. Kanskar, T. Earles, T. J. Goodnough, E. Stiers, D. Botez, and L. J. Mawst: Electron. Lett. 41 (2005) 245.

9) S. Ruder, T. Earles, C. Galstad, M. Klaus, D. Olson, and L. J. Mawst: CLEO2018 (2018) STu4Q.4.

10）上山智, 竹内 哲也, 岩谷 素顕, 赤㟝勇: $\mathrm{GaN}$ 系量子殼構 造の成長と光学特性評価, 日本結晶成長学会誌 45 (2018).

11) Y. Kurisaki, S. Kamiyama, M. Iwaya, T. Takeuchi, and I. Akasaki: Phys. Stat. Sol. A 214 (2017) 1600867.

12) M. Miyoshi, M. Yamanaka, T. Egawa, and T. Takeuchi: Appl. Phys. Express 11 (2018) 051001.

13) T. Lermer, M. Schillgalies, A. Breidenassel, D. Queren, C. Eichler, A. Avramescu, J. Muller, W. Scheibenzuber, U. Schwarz, S. Lutgen, et al.: Phys. Stat. Sol. A 207 (2010) 1328.

14) K. Ikeyama, Y. Kozuka, K. Matsui, S. Yoshida, T. Akagi, Y. Akatsuka, N. Koide, T. Takeuchi, S. Kamiyama, M. Iwaya, et al.: Appl. Phys. Express 9 (2016) 102101.

15) Y. Higuchi, K. Omae, H. Matsumura, and T. Mukai: Appl. Phys. Express 1 (2008) 121102.

16) T. C. Lu, C. C. Kao, H. C. Kuo, G. S. Huang, and S. C. Wang: Appl. Phys. Lett. 92 (2008) 141102.

17) G. Cosendey, A. Castiglia, G. Rossbach, J.-F. Carlin, and N. Grandjean: Appl. Phys. Lett. 101 (2012) 151113.

18) Y. Kozuka, K. Ikeyama, T. Yasuda, T. Takeuchi, S. Kamiyama, M. Iwaya, and I. Akasaki: 2014 MRS Fall Meeting, MRSF141736-T13-08.R1.

19) T. Takeuchi, S. Kamiyama, M. Iwaya, and I. Akasaki: Rep. Prog. Phys. 82 (2016) 012502.

20) E. Hashemi, J. Bengtsson, J. Gustavsson, M. Stattin, G. Cosendey, N. Grandjean, and A. Haglund: Opt. Express 22 (2014) 411.

21) J. T. Leonard, B. P. Yonkee, D. A. Cohen, L. Megalini, S. Lee, J. S. Speck, S. P. DenBaars, and S. Nakamura: Appl. Phys. Lett. 108 (2016) 031111.
22) N. Hayashi, J. Ogimoto, K. Matsui, T. Furuta, T. Akagi, S. Iwayama, T. Takeuchi, S. Kamiyama, M. Iwaya, and I. Akasaki: Phys. Stat. Sol. A 215 (2018) 1700648.

23) M. Kuramoto, S. Kobayashi, T. Akagi, K. Tazawa, K. Tanaka, T. Saito, and T. Takeuchi: Appl. Phys. Lett. 112 (2018) 111104.

24) J. T. Leonard, D. A. Cohen, B. P. Yonkee, R. M. Farrell, T. Margalith, S. Lee, S. P. DenBaars, J. S. Speck, and S. Nakamura: Appl. Phys. Lett. 107 (2015) 011102.

25) S. Yoshida, K. Ikeyama, T. Yasuda, T. Furuta, T. Takeuchi, M. Iwaya, S. Kamiyama, and I. Akasaki: Jpn. J. Appl. Phys. 55 (2016) 05FD10.

26) W. Muranaga, T. Akagi, S. Yoshida, Y. Akatsuka, J. Ogimoto, T. Takeuchi, S. Kamiyama, M. Iwaya, and I. Akasaki: ISPlasma-2018, Nagoya, Japan, March 2018.

27）山本胃勇, ブイヤンアシュラフル G. : 日本真空学会 $\mathbf{5 5}$ (2012) 27.

28) R. Dahal, J. Li, K. Aryal, J. Y. Lin, and H. X. Jiang: Appl. Phys. Lett. 97 (2010) 073115.

29) E. Matioli, C. Neufeld, M. Iza, S. C. Cruz, A. A. Al-Heji, X. Chen, R. M. Farrell, S. Keller, S. DenBaars, U. Mishra, et al.: Appl. Phys. Lett. 98 (2011) 021102.

30) Y. Kuwahara, T. Fujii, T. Sugiyama, D. Iida, Y. Isobe, Y. Fujiyama, Y. Morita, M. Iwaya, T. Takeuchi, S. Kamiyama, et al.: Appl. Phys. Express 4 (2011) 021001.

31) M. Arif, J.-P. Salvestrini, J. Streque, M. B. Jordan, Y. E. Gmili, S. Sundaram, X. Li, G. Patriarche, P. L. Voss, and A. Ougazzaden: Appl. Phys. Lett. 109 (2016) 133507.

32) X. Huang, H. Chen, H. Fu, I. Baranowski, J. Montes, T.-H. Yang, K. Fu, B. P. Gunning, D. D. Koleske, and Y. Zhao: Appl. Phys. Lett. 113 (2018) 043501.

33) M. Mori, S. Kondo, S. Yamamoto, T. Nakao, M. Iwaya, T. Takeuchi, S. Kamiyama, I. Akasaki, and H. Amano: Jpn, J. Appl. Phys. 52 (2013) 08JH02. 